\title{
PERBANDINGAN PENERAPAN MODEL PEMBELAJARAN GUIDED INQUIRY APPROACH DAN MODIFIED FREE INQUIRY APPROACH TERHADAP PEMECAHAN MASALAH MATEMATIKA SISWA
}

\section{THE COMPARISON OF APPLICATION LEARNING MODEL GUIDED INQUIRY APPROACH AND MODIFIED FREE INQUIRY APPROACH TOWARDS SOLUTION OF STUDENT MATHEMATIC PROBLEMS}

\author{
Zainal Basri ${ }^{1}$, Nursalam ${ }^{2}$, Suharti $^{3}$ \\ ${ }^{1,2,3}$ Pendidikan Matematika Universitas Islam Negeri Alauddin Makassar \\ ${ }^{1,2,3}$ Jalan M. Yasin Limpo No. 36 Samata-Gowa \\ E-mail: zainalbasriguna@gmail.com ${ }^{\text {1) }}$, nursalam_ftk@uin-alauddin.ac.id $^{2)}$, \\ suharti.harti@uin-alauddin.ac.id ${ }^{3}$
}

\begin{abstract}
Abstrak:
Penelitian ini bertujuan untuk mengetahui perbandingan model pembelajaran guided inquiry approach dan modified free inquiry approach terhadap pemecahan masalah matematika siswa kelas VIII SMP Negeri 2 Polong bangkeng Utara Kabupaten Takalar. Jenis penelitian ini adalah penelitian eksperimen semu (Quasi Experiment dengan pretest posttest control group design. Dari hasil analisis deskriptif menunjukkan bahwa model pembelajaran guided inquiry approach dan modified free inquiry approach cukup efektif untuk meningkatkan kemampuan pemecahan masalah matematika siswa sedangkan berdasarkan uji hipotesis menunjukkan bahwa tidak terdapat perbedaan signifikan nilai ratarata hasil belajar matematika antara siswa yang diajar menggunakan model pembelajaran guided inquiry approach dan modified free inquiry approach kelas VIII SMPN 2 Polongbangkeng Utara Kabupaten Takalar.
\end{abstract}

Kata Kunci: Pemecahan Masalah, Guided Inquiry Approach, Modified Free Inquiry Approach

Abstract:
This research aims to determine the comparison of learning models guided inquiry approach and modified free inquiry approach to solving the problems of mathematics students of class VIII SMP Negeri 2 Polongbangkeng Utara Kabupaten Takalar. This research type is quasi experiment research with pretest-posttest control group design. From descriptive analysis result shows that guided inquiry approach model and modified free inquiry approach is effective to improve students problem solving abilities of mathematics while based on hypothesis test show that there is no significant difference in mean score of mathematics learning outcomes between students taught using guided inquiry approach model and modified free inquiry approach class VIII SMPN 2 Polongbangkeng Utara Kabupaten Takalar.

Keywords: Problem Solving, Guided Inquiry Approach, Modified Free Inquiry Approach

\section{Pendahuluan}

Pendidikan sangat berperan penting dalam meningkatkan kualitas manusia sebagai salah satu sumber daya pembangunan. Kualitas dari sumber daya manusia suatu 
negara sangat ditentukan oleh kualitas pendidikan yang mereka berikan kepada warga negaranya. Oleh karena itu, suatu negara harus mampu mempersiapkan dan melakukan pembaharuan pendidikan secara terus menerus agar warga negaranya dapat berpartisipasi secara utuh dalam kehidupan bermasyarakat dan dapat bertahan dalam persaingan global seperti dewasa ini.

Berbicara mengenai kualitas pendidikan, pada tahun 2015 Programme for International Study Assessment (PISA) menempatkan Indonesia dengan kualitas pendidikan terendah yakni berada pada peringkat 69 dari 76 negara. Pemeringkatan tersebut didasarkan pada skor yang dicapai siswa usia 15 tahun dalam kemampuan membaca, matematika, dan sains pada ujian nasional dan berbagai tes lainnya (Sarnapi, 2016). Oleh karena itu, pemerintah harus bisa mengupayakan agar mutu pendidikan di Indonesia menjadi lebih baik.

Kualitas pendidikan khususnya di Indonesia dapat ditingkatkan dengan melakukan peningkatan kualitas sumber daya guru dan siswa yang menjadi komponen utama pendidikan. Di tangan gurulah hasil pembelajaran yang merupakan salah satu indikator mutu pendidikan lebih banyak ditentukan. Kualitas pendidikan pada dasarnya dapat dilihat dari proses pembelajaran yang dilakukan guru dan siswa di kelas. Oleh karena itu, kualitas pendidikan sangat erat kaitannya dengan proses pembelajaran yang terjadi di kelas.

Meskipun pemerintah sudah mengupayakan perbaikan untuk mengatasi hasil belajar khususnya matematika, seperti perbaikan kurikulum setiap tahunnya, pengadaan dan perbaikan sarana pembelajaran, peningkatan kualiatas guru melalui berbagai pelatihan, serta melakukan berbagai penelitian yang menjadi faktor-faktor yang diduga dapat mempengaruhi hasil belajar matematika siswa. Namun, kenyataan menunjukkan bahwa hasil belajar matematika siswa masih jauh dari yang diharapkan dan masih banyak siswa yang mengalami kesulitan dalam belajar matematika.

Kemampuan matematika meliputi pemahaman konsep matematis, komunikasi matematis, dan pemecahan masalah. Pencapaian semua kemampuan dianggap masih sulit. Oleh karena itu, dengan meningkatkan salah satu kemampuan tersebut diharapkan dapat menyokong pengembangan kemampuan lainnya. Kemampuan yang dimaksud adalah pemecahan masalah matematika. Hal ini sejalan dengan permendiknas nomor 22 tahun 2006 tentang standar isi menyatakan bahwa salah satu yang menjadi tujuan mata pelajaran matematika diajarkan di sekolah adalah agar siswa mampu memecahkan masalah yang meliputi kemampuan memahami masalah, merancang model matematika, menyelesaikan model dan menafsirkan solusi yang diperoleh (Risqi, 2014). Sehingga kemampuan pemecahan masalah menjadi suatu aspek penting yang harus dikuasai siswa dalam pembelajaran matematika. Berbicara mengenai pemecahan masalah tidak lepas dari tokoh utamanya George Polya. Menurut Polya, dalam pemecahan masalah terdapat empat langkah yang harus dilakukan antara lain: 1) memahami masalah, 2) merencanakan masalah, 3) menyelesaikan masalah, 4) memeriksa kembali hasil yang diperoleh (looking back) (Hasmiah, 2013).

Salah satu cara yang ditempuh untuk meningkatkan kemampuan pemecahan masalah matematika siswa adalah dengan penggunaan model pembelajaran yang tepat dan sesuai dengan karakteristik mata pelajaran maupun kondisi intern sekolah. Penggunaan model pembelajaran yang tepat sangat berpengaruh terhadap hasil belajar siswa. Tujuan utama penggunaan model pembelajaran yang tepat adalah agar siswa bisa aktif dan tertarik dengan pembelajaran yang disajikan serta tujuan pembelajaran dapat tercapai dengan baik. Selain model pembelajaran kooperatif dengan berbagai tipe ada 
beberapa model pembelajaran yang membuat siswa ikut serta aktif dalam proses pembelajaran diantaranya adalah model pembelajaran inkuiri. Berdasarkan hasil penelitian oleh Yenny (2014), menyimpulkan bahwa model pembelajaran inkuiri lebih efektif dan berpengaruh terhadap kemampuan pemecahan masalah matematis dibanding dengan menggunakan pendekatan pembelajaran konvensional.

Menurut Oemar, pengajaran berdasarkan inkuiri (inquiry-based teaching) adalah suatu strategi yang berpusat pada siswa (student centered strategy) dimana kelompokkelompok siswa kedalam suatu persoalan atau mencari jawaban terhadap pertanyaanpertanyaan didalam suatu prosedur dan struktur kelompok yang digariskan secara jelas. Sehingga model pembelajaran inkuiri merupakan salah satu model yang dapat mendorong siswa untuk aktif dalam pembelajaran (Oemar, 2009). Mendorong siswa untuk belajar aktif adalah salah satu cara agar siswa dapat berpikir kritis dan mampu menyelesaikan setiap permasalahan yang diberikan.

Ada beberapa keunggulan dari model inkuiri antara lain: 1) mendorong siswa untuk bisa berpikir secara ilmiah dalam memecahkan masalah yang dihadapi. 2) membantu dalam menggunakan ingatan, dan transfer pengetahuan pada situasi proses pengajaran. 3) mendorong siswa untuk berpikir kreatif dan intuitif serta bekerja atas dasar inisiatif sendiri. Kemudian pada dasarnya model pembelajaran inkuiri terbagi menjadi tiga jenis berdasarkan besarnya intervensi guru terhadap siswa atau besarnya bimbingan yang diberikan oleh guru kepada siswanya. Ketiga jenis pendekatan inquiri tersebut adalah: 1) inkuiri terbimbing (guided inquiry approach), 2) inquiri bebas (free inquiry approach), 3) inkuiri bebas yang dimodifikasikan (modified free inquiry approach) (Zainal dkk, 2016).

Pembelajaran inkuiri terbimbing (guided inquiry) adalah suatu model pembelajaran inkuiri yang sebagian perencanaan dibuat oleh peserta pendidik. Selain itu pendidik menyediakan kesempatan bimbingan atau petunjuk yang cukup luas kepada siswa (Zainal dkk, 2016). Dalam hal ini, siswa tidak merumuskan problem, sementara petunjuk yang cukup luas tentang bagaimana menyusun dan mencatat diberikan oleh pendidik. Sedangkan model pembelajaran modified free Inquiry merupakan modifikasi dari free inquiry dengan open-ended inquiry. Dalam pembelajaran ini pendidik hanya memberikan pokok permasalahan. Biasanya disediakan pula bahan dan alat-alat yang diperlukan, kemudian peserta didik diundang untuk memecahkan sebuah masalah melalui pengamatan, eksplorasi, atau melalui prosedur penelitian untuk memperoleh jawabannya (Zainal dkk, 2016). Pemecahan masalah dilakukan atas inisiatif dan caranya sendiri. Model pembelajaran modified free inquiry hanya memberikan peran kepada pendidik sebagai pendorong, narasumber, dan memberikan bantuannya yang diperlukan untuk menjamin kelancaran proses belajar peserta didik. Sehingga dalam model ini peserta didik diberikan kebebasan dalam menentukan rencana dan memecahkan sendiri masalah yang diberikan.

Dari berbagai uraian masalah diatas, maka perlu diadakan penelitian untuk membandingkan sejauh mana tingkat efektivitas kedua model pembelajaran tersebut. Dalam hal ini, penulis bermaksud meneliti tentang "Perbandingan model pembelajaran guided inquiry approach dan modified free inquiry approach terhadap pemecahan masalah matematika peserta didik kelas VIII SMP Negeri 2 Polongbangkeng Utara Kabupaten Takalar". 


\section{Metode Penelitian}

Penelitian ini merupakan penelitian kuantitatif jenis eksperimen. Populasi pada penelitian ini adalah peserta didik kelas VIII SMP Negeri 2 Polongbangkeng Utara Kabupaten Takalar tahun ajaran 2017/2018 sebanyak 145 orang. Sampel diambil dengan teknik purposive sampling dan diperoleh kelas VIII.A sebagai kelas eksperimen I dan kelas VIII.B sebagai kelas eksperimen II yang masing-masing berjumlah 24 orang. Desain penelitian ini menggunakan Pretest Posttest Control Group Design.

Teknik pengumpulan data dalam penelitian ini meliputi tes dan observasi. Tes yang digunakan adalah jenis tes tertulis bentuk uraian dengan materi aljabar yang terdiri dari pretest dan posttest, bertujuan untuk mengetahui kemampuan pemecahan masalah matematis peserta didik. Sedangkan observasi meliputi pengamatan terhadap pelaksanaan pembelajaran dan pengamatan terhadap peserta didik selama proses pembelajaran. Kemudian untuk mengetahui kelayakan dan kekonsistenan instumen tes yang digunakan maka sebelumnya dilakukan uji validitas butir soal dengan menggunakan validitas konstruk (construct validity) dan uji reliabilitas menggunakan teknik alpha croncbach's. hasilnya dapat dilihat pada tabel berikut:

Tabel 1. Hasil Uji Validitas Butir Soal Pretest

\begin{tabular}{cccc}
\hline Nomor Soal & Nilai Sig. & Pearson Correlation & Keterangan \\
\hline 1 & 0.001 & 0.8 & Valid \\
2 & 0.001 & 0.9 & Valid \\
3 & 0.001 & 0.9 & Valid \\
4 & 0.001 & 0.8 & Valid \\
5 & 0.001 & 0.8 & Valid \\
\hline
\end{tabular}

Berdasarkan tabel 1 diatas, menunjukkan bahwa semua butir pretest soal memiliki koefisien product moment diatas 0,3 atau nilai sig $\leq \alpha(\alpha=0,05)$ artinya butir soal pretest tersebut valid atau layak digunakan untuk mengukur kemampuan pemecahan masalah matematika peserta didik.

Tabel 2. Hasil Uji Validitas Butir Soal Posttest

\begin{tabular}{cccc}
\hline Nomor Soal & Nilai Sig. & Pearson Correlation & Keterangan \\
\hline 1 & 0.001 & 0.6 & Valid \\
2 & 0.001 & 0.5 & Valid \\
3 & 0.001 & 0.6 & Valid \\
4 & 0.001 & 0.6 & Valid \\
5 & 0.001 & 0.6 & Valid \\
\hline
\end{tabular}

Berdasarkan tabel 2, menunjukkan bahwa semua butir soal posttest memiliki koefisien product moment diatas 0,3 atau nilai sig $\leq \alpha(\alpha=0,05)$ yang artinya butir soal posttest tersebut valid atau layak digunakan untuk mengukur kemampuan pemecahan masalah matematika siswa.

Tabel 3. Hasil Uji Reliabilitas Butir Soal

\begin{tabular}{ccc}
\hline Butir Soal & Cronbach's Alpha & Keterangan \\
\hline Pre test & 0.927 & Reliabel \\
Post test & 0.643 & Reliabel \\
\hline
\end{tabular}


Hasil uji reliabilitas pada tabel 3 menunjukkan bahwa harga Cronbach's Alpha untuk butir soal pretest dan posttest jika dikonsultasikan dengan standar reliabilitas $(0,6)$ maka harga Cronbach's Alpha tersebut lebih besar dari standar reliabilitas. Jadi, dapat disimpulkan bahwa instrumen butir soal pretest dan posttest telah reliabel atau dalam artian apabila dilakukan pengukuran dua kali atau lebih dengan tujuan yang sama serta menggunakan instrumen yang sama maka hasilnya akan tetap konsisten. Analisis hasil tes kemampuan pemecahan masalah matematika menggunakan analisis deskriptif dan analisis inferensial yaitu uji-t sampel independen dengan terlebih dahulu melakukan uji persyaratan analisis yakni uji normalitas dan uji homogenitas.

\section{Hasil dan Pembahasan}

Deskripsi hasil penelitian kelas eksperimen I dan kelas eksperimen II dapat dilihat pada tabel berikut:

Tabel 4. Kategorisasi Kemampuan Pemecahan Masalah Matematika Peserta Didik Kelas Eksperimen I (Prettest)

\begin{tabular}{ccccc}
\hline No. & $\begin{array}{c}\text { Skor Peserta } \\
\text { Didik }\end{array}$ & Frekuensi & Persentase & Kategori \\
\hline 1 & $20-34$ & 24 & $100 \%$ & Kurang \\
2 & $35-50$ & 0 & $0 \%$ & Cukup \\
3 & $51-65$ & 0 & $0 \%$ & Baik \\
4 & $66-80$ & 0 & $0 \%$ & Sangat baik \\
\hline
\end{tabular}

Berdasarkan hasil pretest pada tabel 4 menunjukkan bahwa kondisi awal atau kemampuan awal peserta didik kelas eksperimen I (VIII.A) sebelum diberi perlakuan model pembelajaran guided inquiry approach masih berada pada kategori kurang atau rendah dalam hal pemecahan masalah matematika, dan tak seorang pun siswa yang berada pada kategori cukup, baik, dan baik sekali.

Tabel 5. Kategorisasi Kemampuan Pemecahan Masalah Matematika Peserta Didik Kelas Eksperimen I (Posttest)

\begin{tabular}{ccccc}
\hline No. & $\begin{array}{c}\text { Skor Peserta } \\
\text { Didik }\end{array}$ & Frekuensi & Persentase & Kategori \\
\hline 1 & $20-34$ & 7 & $29.17 \%$ & Kurang \\
2 & $35-50$ & 17 & $70.83 \%$ & Cukup \\
3 & $51-65$ & 0 & $0 \%$ & Baik \\
4 & $66-80$ & 0 & $0 \%$ & Sangat baik \\
\hline
\end{tabular}

Hasil posttest kelas eksperimen I (VIII.A) pada tabel 5 menunjukkan bahwa kemampuan pemecahan peserta didik setelah diberi perlakuan model pembelajaran guided inquiry approach sebanyak $70.83 \%$ peserta didik sudah berada kategori cukup dan lebihnya $29.17 \%$ masih berada pada kategori kurang.

Tabel 6. Kategorisasi Kemampuan Pemecahan Masalah Matematika Peserta Didik Kelas Eksperimen II (Pretest)

\begin{tabular}{|c|c|c|c|c|}
\hline No. & $\begin{array}{l}\text { Skor Peserta } \\
\text { Didik }\end{array}$ & Frekuensi & Persentase & Kategori \\
\hline
\end{tabular}




\begin{tabular}{ccccc}
\hline \hline 1 & $20-34$ & 20 & $83.33 \%$ & Kurang \\
2 & $35-50$ & 4 & $16.67 \%$ & Cukup \\
3 & $51-65$ & 0 & $0 \%$ & Baik \\
4 & $66-80$ & 0 & $0 \%$ & Sangat baik \\
\hline
\end{tabular}

Berdasarkan hasil pretest pada kelas eksperimen II di atas dapat diketahui bahwa dari keseluruhan peserta didik, terdapat $20(83,33 \%)$ peserta didik berada pada kategori kurang, terdapat $4(16,67 \%)$ peserta didik yang berada pada kategori cukup, dan tidak terdapat peserta didik yang berada kategori baik serta sangat baik dalam hal pemecahan masalah matematika.

Tabel 7. Kategorisasi Kemampuan Pemecahan Masalah Matematika Peserta Didik Kelas Eksperimen II (Posttest)

\begin{tabular}{ccccc}
\hline No. & $\begin{array}{c}\text { Skor Peserta } \\
\text { Didik }\end{array}$ & Frekuensi & Persentase & Kategori \\
\hline 1 & $20-34$ & 9 & $37.5 \%$ & Kurang \\
2 & $35-50$ & 15 & $62.5 \%$ & Cukup \\
3 & $51-65$ & 0 & $0 \%$ & Baik \\
4 & $66-80$ & 0 & $0 \%$ & Sangat baik \\
\hline
\end{tabular}

Berdasarkan hasil posttest kelas eksperimen II diatas dapat diketahui bahwa dari keseluruhan peserta didik, terdapat $9(37,5 \%)$ peserta didik yang masih berada pada kategori kurang, terdapat $15(62,5 \%)$ peserta didik yang berada pada kategori cukup, dan tidak terdapat peserta didik yang berada pada kategori baik dan sangat baik dalam hal pemecahan masalah matematika.

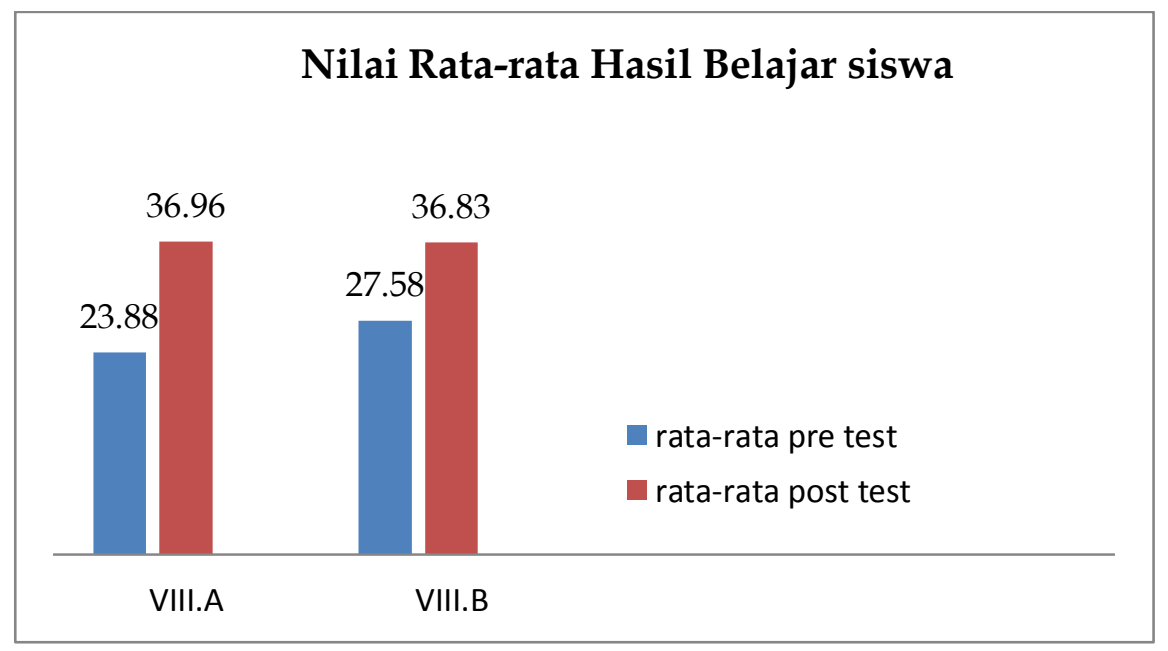

Gambar 1. Perbandingan Nilai Rata-rata Hasil Belajar Peserta Didik

Dari gambar 1 menunjukkan bahwa rata-rata pretest kelas VIII.A sebesar 23.88 dan rata-rata posttest sebesar 36.96 dengan peningkatan sebesar 13.08 sedangkan ratarata pretest pada kelas VIII.B sebesar 27.58 dan rata-rata posttest sebesar 36.83 dengan peningkatan sebesar 9.25. 
Uji Hipotesis pada penelitian ini menggunakan uji-t sampel independen yang terlebih dahulu melakukan uji persyaratan analisis yang terdiri dari uji normalitas dan uji homogenitas. Adapun hasilnya sebagai berikut:

Uji normalitas bertujuan untuk mengetahui apakah data dari masing-masing kelas berdistribusi normal atau tidak, baik kelas yang menggunakan model pembelajaran guided inquiry approach (kelas eksperimen I) maupun model pembelajaran modified free inquiry approach (kelas eksperimen II). Pada uji normalitas peneliti menggunakan metode Kolmogorov-Smirnov, Adapun hasilnya sebagai berikut:

Tabel 8. Hasil Uji Normalitas Data

\begin{tabular}{cccc}
\hline Kelas & $D_{\text {hitung }}$ & Sig. & Keterangan \\
\hline VIII.A & 0.170 & 0.071 & Normal \\
VIII.B & 0.113 & 0.200 & Normal \\
\hline
\end{tabular}

Dari tabel 8 dapat dilihat bahwa nilai signifikan pada kelas VIII.A adalah sebesar 0,071 dan nilai signifikan untuk kelas VIII.B sebesar 0,200 menunjukkan bahwa nilai signifikansi masing-masing kelas lebih besar dari $\propto=0,05$ maka dapatkan disimpulkan bahwa $\mathrm{H}_{0}$ diterima atau kedua kelas memiliki data yang berdistribusi normal. Sedangkan jika membandingkan antara $D_{\text {hitung }}$ dengan $D_{\text {tabel }}$ dimana $D_{\text {tabel }}$ $\left(D_{(0,05,23)}\right)$ yakni sebesar 0,275 maka kedua kelas memiliki $D_{\text {hitung }}<D_{\text {tabel }}$ artinya $\mathrm{H}_{0}$ juga diterima atau data berdistribusi dengan normal atau baik.

Uji homogenitas varians dimaksudkan untuk mengetahui apakah kedua kelas mempunyai varians (keragaman) yang tidak jauh berbeda. Adapun hasilnya sebagai berikut:

Tabel 9. Hasil Uji Homogenitas Data

\begin{tabular}{cccc}
\hline Levene Statistic & df1 & df2 & Sig. \\
\hline 0.128 & 1 & 46 & 0.722 \\
\hline
\end{tabular}

Berdasarkan tabel 9 dapat diketahui nilai signifikansi sebesar 0,722. Nilai ini menunjukkan bahwa sign $>\propto=0.722>0,05$ artinya $\mathrm{H}_{0}$ diterima atau dapat disimpulkan bahwa kedua kelas memiliki varian yang sama atau homogen.

Setelah uji persyaratan analisis terpenuhi yakni data berdistribusi normal dan homogen maka untuk uji hipotesisnya digunakan uji-t untuk sampel independen. Adapun hipotesisnya sebagai berikut:

Hipotesis dalam uraian kalimat:

$$
\begin{aligned}
& H_{0}: \mu_{1}=\mu_{2} \\
& H_{1}: \mu_{1} \neq \mu_{2}
\end{aligned}
$$

$H_{0}$ : Tidak terdapat perbedaan signifikan nilai rata-rata hasil belajar matematika antara peserta didik yang diajar menggunakan model pembelajaran guided inquiry approach dan modified free inquiry approach kelas VIII SMPN 2 Polongbangkeng Utara.

$H_{1}$ : Terdapat perbedaan signifikan nilai rata-rata hasil belajar matematika antara peserta didik yang diajar menggunakan model pembelajaran guided inquiry approach dan modified free inquiry approach kelas VIII SMPN 2 Polongbangkeng Utara. 
Tabel 10. Hasil Uji-t Sampel Independen

\begin{tabular}{cccccc}
\hline Kelas & $\mathrm{N}$ & Mean & Std. deviasi & $t_{\text {hitung }}$ & Sig. \\
\hline VIII.A & 24 & 36.96 & 5.120 & 0.088 & 0.930 \\
VIII.B & 24 & 36.83 & 4.699 & 0.088 & 0.930 \\
\hline
\end{tabular}

Dari tabel 10 dapat diketahui bahwa nilai signifikansi sebesar 0,930. Nilai ini menunjukkan bahwa sign $>\propto=0.930>0,025$ sehingga $\mathrm{H}_{0}$ diterima atau dengan melihat nilai $t_{\text {hitung }}$ sebesar 0,088 maka jika dibandingkan dengan $t_{\text {tabel }}\left(t_{(0,025,46)}\right)$ sebesar 2,012 maka $-t_{\text {tabel }} \leq t_{\text {hitung }} \leq t_{\text {tabel }}$ atau $-2,012 \leq 0,088 \leq 2,012$ artinya $\mathrm{H}_{0}$ diterima atau disimpulkan bahwa tidak terdapat perbedaan signifikan nilai rata-rata hasil belajar matematika antara peserta didik yang diajar menggunakan model pembelajaran guided inquiry approach dan modified free inquiry approach kelas VIII SMPN 2 Polongbangkeng Utara.

Model pembelajaran guided inquiry approach merupakan model pembelajaran yang diterapkan pada kelas eksperimen I (kelas VIII.A) selama enam kali pertemuan. Sebelum model pembelajaran ini dipercobakan terlebih dahulu diadakan pretest untuk mengetahui kondisi awal peserta didik atau kemampuan pemecahan masalah matematika. Hasil pretest dapat dilihat pada tabel 4, berdasarkan hasil pretest tersebut dapat dilihat bahwa kondisi awal atau kemampuan awal peserta didik sebelum diberikan perlakuan menunjukkan bahwa kemampuan pemecahan masalah matematika peserta didik masih berada pada kategori kurang atau rendah, dan tak seorang pun peserta didik yang berada pada kategori cukup, baik dan baik sekali. Dari jawaban hasil pretest siswa juga menunjukkan bahwa kemampuan pemecahan masalah dari empat indikator yang diujikan, peserta didik belum mampu memahami masalah yang diberikan sehingga terkendala dalam menyelesaikan soal-soal tersebut. Kemudian berdasarkan hasil posttest pada tabel 5, menunjukkan bahwa dari keseluruhan peserta didik kelas VIII.A, setelah mendapat perlakuan model pembelajaran guided inquiry approach, terdapat 7 $(29,17 \%)$ peserta didik masih ada pada kategori kurang dalam hal pemecahan masalah matematika, dan selebihnya yakni $17(70,83 \%)$ peserta didik sudah berada pada kategori cukup dalam hal pemecahan masalah matematika. Dari hasil pretest dan posttest yang dilakukan dapat dilihat bahwa sebelum dan sesudah model pembelajaran diterapkan terdapat peningkatan hasil belajar matematika peserta didik tetapi yang cukup signifikan, hal ini dapat dilihat pada lampiran data hasil penelitian yang menunjukkan bahwa kemampuan pemecahan masalah matematika peserta didik sudah mulai meningkat, hal ini dapat dilihat dari jawaban peserta didik yang mulai bisa memahami masalah seperti peserta didik mampu menuliskan apa yang diketahui dan ditanyakan pada soal. Hal yang sama juga dapat dilihat pada rata-rata skor pretest peserta didik yang awalnya sebesar 23,88 kemudian meningkat menjadi 36,96. Peningkatan skor ratarata hasil belajar setelah diajar menggunakan model pembelajaran guided inquiry approach sebesar 13,08, menunjukkan bahwa model pembelajaran guided inquiry approach cukup efektif meningkatkan kemampuan pemecahan masalah matematika peserta didik SMP. 
Model pembelajaran modified free inquiry approach merupakan model pembelajaran yang diterapkan pada kelas eksperimen II (kelas VIII.B) selama enam kali. Berdasarkan hasil pretest dapat dilihat pada tabel 6, menunjukkan bahwa kemampuan awal peserta didik kelas VIII.B juga masih rendah, 20 (83,33\%) siswa masih berada pada kategori kurang, dan terdapat $4(16,67 \%)$ peserta didik yang sudah berada pada kategori cukup, dalam hal pemecahan masalah matematika. Setelah diadakan pretest dan menganalisis hasil pretest tersebut kemudian dilakukan percobaan model pembelajaran yakni modified free inquiry approach selama enam kali pertemuan. Untuk mengetahui efektivitas dari model pembelajaran ini maka pada pertemuan terakhir juga diadakan posttest. Hasil posttest dapat dilihat pada tabel 7, menunjukkan bahwa setelah mendapatkan perlakuan dari model pembelajaran modified free inquiry approach dari keseluruhan peserta didik, terdapat 9 (37,5\%) siswa yang masih berada pada kategori kurang, namun sudah terdapat $15(62,5 \%)$ peserta didik yang berada pada kategori cukup dalam hal pemecahan masalah matematika. Dari rata-rata skor pretest peserta didik yakni sebesar 27,58 dan meningkat menjadi 36,83. Hal ini dapat dilihat pada gambar 1 menunjukkan peningkatan hasil belajar setelah diajar menggunakan model pembelajaran guided inquiry approach adalah sebesar 9,25 menunjukkan bahwa model pembelajaran guided inquiry approach cukup efektif dalam meningkatkan kemampuan pemecahan masalah matematika SMP.

Berdasarkan hasil posttest kedua model pembelajaran menunjukkan bahwa kedua model cukup efektif meningkatkan kemampuan pemecahan masalah matematika peserta didik SMP walaupun dengan waktu singkat dalam artian jika dikaitkan dengan teori pada BAB II, sudah sesuai bahwa jika model pembelajaran diimplementasikan secara terus-menerus maka kemampuan pemecahan masalah matematika peserta didik akan meningkat lebih baik. Hal ini juga sejalan dengan hasil penelitian yang dilakukan oleh Yenny bahwa model pembelajaran inquiry dapat meningkatkan kemampuan pemecahan masalah matematis peserta didik dibanding dengan menggunakan model pembelajaran konvesional.

Berdasarkan hasil uji hipotesis dengan bantuan aplikasi SPSS versi 21 dapat dilihat pada tabel 10 bahwa nilai signifikansi sebesar 0,930. Nilai ini menunjukkan bahwa sign $>\propto=0.930>0,025$ sehingga $\mathrm{H}_{0}$ diterima atau dengan melihat nilai $t_{\text {hitung }}$ sebesar 0,088 maka jika dibandingkan dengan $t_{\text {tabel }}\left(t_{(0,025,46)}\right)$ sebesar 2,012 maka $-t_{\text {tabel }} \leq t_{\text {hitung }} \leq t_{\text {tabel }}$ atau $-2,012 \leq 0,088 \leq 2,012$ artinya $\mathrm{H}_{0}$ diterima atau disimpulkan bahwa tidak terdapat perbedaan signifikan nilai rata-rata hasil belajar matematika antara peserta didik yang diajar menggunakan model pembelajaran guided inquiry approach dan modified free inquiry approach kelas VIII SMPN 2 Polongbangkeng Utara. Dengan kata lain model pembelajaran dengan tipe terbimbing dan yang sudah dimodifikasi sama-sama efektif meningkatkan kemampuan pemecahan matematika peserta didik kelas VIII SMP. Berdasarkan dari hasil uji hipotesis yang menunjukkan tidak adanya perbedaan kedua model dalam pemecahan masalah matematika, menunjukkan kemungkinan bahwa kelas VIII.B memiliki kemampuan pemecahan matematika lebih baik dari kelas VIII.A, karena walaupun kelas VIII.B hanya mendapatkan sedikit bimbingan dari guru dalam merumuskan masalah tetapi peningkatan hasil kemampuan pemecahan matematika peserta didik kelas VIII.B dapat menyamai kemampuan matematis peserta didik kelas VIII.A yang diberi bimbingan sepenuhnya. 


\section{Kesimpulan}

Berdasarkan hasil penelitian dan uraian pembahasan tersebut, maka dapat ditarik kesimpulan sebagai berikut:

1. Model pembelajaran guided inquiry approach cukup efektif meningkatkan kemampuan pemecahan masalah matematika peserta didik kelas VIII SMPN 2 Polongbangkeng Utara Kabupaten Takalar.

2. Model pembelajaran modified free inquiry approach cukup efektif meningkatkan kemampuan pemecahan masalah matematika siswa kelas VIII SMPN 2 Polongbangkeng Utara Kabupaten Takalar.

3. Tidak terdapat perbedaan signifikan efektivitas model pembelajaran guided inquiry approach dan modified free inquiry approach dalam pemecahan masalah matematika siswa kelas VIII SMPN 2 Polongbangkeng Utara Kabupaten Takalar.

\section{Daftar Pustaka}

Aqib, Z. \& Ali, M. (2016). Kumpulan Metode Pembelajaran Kreatif dan Inovatif. Bandung: Satu Nusa.

Arikunto, S. (2002). Dasar-Dasar Evaluasi Pendidikan (edisi revisi). Jakarta: Bumi Aksara.

Depdiknas. (2006). Peraturan Menteri Pendidikan Nasional Republik Indonesia tentang standar Isi Untuk satuan Pendidikan dasar dan Menengah. Jakarta.

Emzir. (2014). Metodologi Penelitian Pendidikan Kuantitatif dan Kualitatif. Depok: PT Raja Grafindo.

Hamalik, O. (2009). Pendekatan Baru Strategi Belajar Mengajar Berdasarkan CBSA Menuju Profesionalitas Guru dan Tenaga Pendidik. Bandung: Sinar Baru Algensindo.

Mustamin, S. H., (2013). Psikologi Pembelajaran Matematika. (Cet. 1; Makassar: Alauddin University Press).

Rahman, R. (2014). Pengaruh Penggunaan Metode Discovery terhadap Kemampuan Analogi Matematis Siswa SMK Al-Ikhsan Pamarican Kabupaten Ciamis Jawa Barat. Jurnal Ilmiah. No. 1. 2014.

Sarnapi. (2016). Peringkat Pendidikan Indonesia masih Rendah, Pikiran-rakyat.com. 18 Juni 2016. http://www.pikiran-rakyat.com (23 September 2017)

Sarwi. (2015). Utilization Of The Guided Inquiry Learning Model to Develop Students Concervation Character, International Conference on Mathematics, Science, And Education.

Siregar, S. (2014). Statistik Parametrik Untuk Penelitian Kuantitatif. Jakarta: Bumi Aksara.

Sugiyono. (2016). Metode Penelitian Pendidikan. Cet XXIII. Bandung: Alfabeta. 
Ural, E. (2016). The Effect of Guided-Inquiry Laboratory Experiment on Science Education Students Chemistry Laboratory Attitudes, Anxiety and Achievement. Journal of Education and Training Studies, Vol. 4 No. 4. hal. 223.

Wang, P. (2013). The Learning Effectiveness of Inquiry-Based Instruction Among Vocational High School Students. Journal of Educational Research International, Vol. 2 No. 2. hal. 22.

Widowati, A. (2008). Impoving The Divergent Thinking Skill Using The Modified Free Inquiry Approach to Teaching Science. Journal of Education, Vol. 11 No. 1. hal. 124.

Yenny, M. (2014). Pengaruh Pendekatan Inkuiri Terbimbing Terhadap Peningkatan Kemampuan Pemecahan Masalah Matematis Siswa SMP. Jurnal Pendidikan dan Keguruan, Vol. 1 No. 2. hal 9. 